\title{
Research on the Influence of Cultural Distance on China's OFDI Reverse Technology Spillover in the Background of the Belt and Road
}

\author{
Miaoyang Dong \\ School of Economics and Management, Nanjing University of Science \& Technology, Nanjing, Jiangsu 210094, China \\ Email:13262208783@163.com
}

\begin{abstract}
Based on the multinational panel data of the countries along the Belt and Road (B\&R countries) from 2005 to 2017 , this paper uses the gravity model to study the impact of the cultural distance between China and the host country on China's reverse technology spillover. The research shows that the cultural differences between the host country and China hinder the reverse technology spillover of China's foreign direct investment to a certain extent. Further, this study finds that the technology distance between the host country and China and the host country's R\&D capital stock can significantly promote the reverse technology spillover. And geographic distance doesn't have a significant impact on the OFDI reverse technology spillover in the stochastic fixed-effects model. Therefore, Chinese enterprises that 'go out' must pay attention to the local cultural environment of the host country and strengthen the transnational cultural construction of enterprises. This paper also proposes relevant policies and suggestions for the formulation of China's foreign direct investment strategy and the improvement of its cultural environment under the Belt and Road initiative (BRI).
\end{abstract}

Keywords: the Belt and Road, cultural distance, OFDI, reverse technology spillover

\section{INTRODUCTION}

Since President Xi Jinping proposed the co-construction of BRI in 2013, China's foreign direct investment (OFDI) has grown rapidly. In 2018, China's OFDI to countries or regions in the world was US $\$ 143.04$ billion, ranking second in the world, and its stock was as high as US $\$ 1.98$ trillion, ranking third in the world. In recent years, the total size of China's OFDI has grown rapidly. Regardless of the distribution of investment destination countries or industry distribution, the scope involved has been rapidly covering. From joining the APEC and World Trade Organization to launching BRI, China has extensively participated in international trade and division of labor, established good trade partnerships with countries, and actively assumed the responsibility of major powers. While improving its own economic strength, China is also actively developing mutually beneficial cooperation with other countries through trade and OFDI, which has injected new vitality into the economic development of partners.

Since the Trump administration came to power, the United States has withdrawn from the Trans-Pacific Partnership and has successively introduced a series of trade protection policies, which has not only caused greater uncertainty in the recovery of the global economy and trade, but also brought great challenges to the sustainable development of China's export trade. Under the background of the rise of anti globalization and the prevalence of trade protectionism, especially the continued escalation of SinoUS trade disputes, Chinese companies have responded positively to BRI and actively carried out OFDI for B\&R countries, which is not only conducive to hedging the adverse effects of the Sino-US trade war, but also expands their own income while bringing the host country the necessary construction funds and other factors. At the same time, additional benefits, including reverse technology spillovers, can be achieved through this investment, which can help promote domestic economic development. At a macro level, OFDI for B\&R countries is also conducive to enhancing China's national reputation and international influence, and reflecting China's image as a responsible power.

Currently, B\&R countries has become one of the key areas of OFDI in China. During the investment and operation of local countries along the route, the relevant reverse technology spillover effects are also emerging. However, $B \& R$ covers a wide range of countries, and its political, economic and cultural conditions are intricate and complicated, all of which have had a complex impact on Chinese companies' OFDI reverse technology spillovers. In particular, due to the obvious existence of cultural distance, cultural factors constitute an important factor which affects Chinese companies' OFDI reverse technology spillovers. The facts indicate that in the process of investing $\mathrm{B} \& \mathrm{R}$ countries, companies must pay special attention to the impact of cultural differences due to cultural distance, respect local religious beliefs, lifestyles, 
cultural practices, etc., in order to exert greater OFDI reverse technology spillover effect.

\section{LITERATURE REVIEW}

So far, scholars at home and abroad have done a lot of research on the impact of cultural distance on OFDI. Thomas[1] studied the investment situation of OECD countries in Mexico and found that the greater the cultural distance between the two countries, the more willing multinational companies are to invest. This may be because cultural distance brings product differentiation to enterprises and consumers in host countries. Qi Jianhong et al.[2] used four methods to measure cultural distance indicators. According to the PCSE model analysis, the relationship between cultural distance and OFDI location selection was not a simple linear relationship, and there might be a threshold effect. Furthermore, it was found that cultural distance and China OFDI presents a U-shaped relationship.

In terms of the research on the influencing factors of OFDI reverse technology spillover effects, domestic and foreign scholars have also done a lot of research. Andref[3] believed that the technical level of the home country is not the main factor affecting the country's OFDI, and the technical level of the host country has a greater impact on the OFDI of the enterprise. Keller[4] believed that the geographical distance and time between the two countries will affect the reverse technology spillover of OFDI. Sha Wenbing[5] studied from the perspective of the degree of innovation and economic development of the host country and believed that the host country's R \& D input level and per capita GDP have a significant positive impact on China's OFDI reverse technology spillover.

Based on comprehensive research at home and abroad, it can be seen that the transmission mechanism between cultural distance and OFDI reverse technology spillover can be roughly divided into three aspects: First, cultural distance will increase the coordination costs of enterprises. If there is a large cultural difference, there may be internal differences in the resource allocation, market opportunities, corporate values, and corporate management structure, which will hinder the reverse technology spillover of companies. Second, cultural distance will increase the difficulty for companies to understand knowledge. If the cultural differences between the two countries are too large, the barriers to understanding technical knowledge and other aspects will increase, the difficulty of understanding will increase, and the accuracy and timeliness of technology acquisition will be hindered. Third, cultural distance will increase the difficulty for multinational companies to integrate into the local environment, and the more difficult it is for companies to integrate into host countries, the lower the ability to acquire technology.

Generally speaking, most of the researches on the influencing factors of OFDI reverse technology spillover are conducted from the perspective of the host country or home country system, while few researches focus on the influence of cultural distance on reverse technology spillover. At present, China's OFDI for B\&R countries continues to grow, and with the increasing strength of science and technology, we will pay more attention to the host country's technological level in the future OFDI location selection of B\&R countries. This paper takes the Belt and Road as the background, and studies the influence of cultural distance on China's reverse technological spillover of OFDI in B\&R countries, which has good theoretical value and practical significance.

\section{EMPIRICAL ANALYSIS}

\subsection{Model Setting}

Based on previous theories and scholars' research, this paper draws on the variable selection of the gravity model, and establishes the following gravity model to analyze the efficiency difference of China's OFDI in B\&R countries.

$\operatorname{LnSOFDI}_{i, t}=\beta 0+\beta 1 C D_{i, t}+\beta 2 \operatorname{LnGDP} 1_{i, t}+\beta 3 \operatorname{LnGDP} 2_{j, t}+$ $\beta 4 \operatorname{LnTech}_{i, t}+\beta 5 \operatorname{LnDIS} \mathrm{S}_{i, t}+\operatorname{LnRD}_{i, t}+\varepsilon_{i, t}$

Among them, i represents $B \& R$ countries, $j$ represents the home country (that is, China), SOFDI refers to the R\&D capital stock of host country spillover from China's OFDI in $B \& R$ countries in year $t ; C D$ is the cultural difference between China and B\&R countries in year t; GDP1 refers to the GDP of B\&R country $i$ in year $t$, and GDP2 refers to the GDP of China in year $t$; Tech refers to the technology distance between China and the B\&R host country i; DIS is the geographical distance between China and the B\&R country in year t. RD refers to the stock of R\&D capital in the host country.

Based on the availability of data, this paper selects data from 2005 to 2017. The B\&R countries include Albania, Bulgaria, Croatia, Czech Republic, Egypt, Estonia, Hungary, India, Indonesia, Iran, Israel, Jordan, Latvia, Lithuania, Malaysia, Pakistan, Philippines, Poland, Romania, Russia, Saudi Arabia, Singapore, Slovakia, Slovenia, Thailand, Turkey, Ukraine, United Arab Emirates, and Vietnam, a total of 29 countries, constitute the panel data.

\subsection{Variable definition and Data Source}

(1) SOFDI is measured by the Lichtenberg and Pottelsberghe method (2001). The calculation method is:

$$
\text { SOFDI } I_{i, t}=\left(\text { YOFDI }_{i, t} / K_{i, t}\right) S_{i, t}
$$

YOFDI is the OFDI stock of China's OFDI in B\&R country $j$ in year $t$; $K$ is the fixed capital stock of country $i$ in year $t ; S$ is the domestic R\&D capital stock of country $i$ in year $\mathrm{t} ; \mathrm{S}$ is calculated as:

$$
S_{i, t}=R \& D_{i, t}+(1-\delta) S_{i, t-1}
$$

The R\&D calculation method of country $i$ in year $t$ is to obtain the total GDP and the proportion of R\&D in GDP of each country in 2005-2017 from the World Bank database. $\mathrm{S}_{\mathrm{i}, \mathrm{t}-1}$ is the is the domestic R\&D capital stock of 
country $\mathrm{i}$ in the previous period. $\delta$ is the depreciation rate of R\&D capital. This article refers to previous studies and uses a $5 \%$ depreciation rate. $R \& D_{i, t}$ is the foreign $R \& D$ capital stock in year i converted from the base period in 2005. When calculating the capital stock in the base period, this article uses the following formula to calculate:

$$
S_{i, 2005}=R \& D_{i, 2005} /(g+\delta)
$$

Among them, $\mathrm{g}$ is the arithmetic average growth rate of R\&D expenditure flows of each country from 2005 to 2017, and is selected as 5\% conventionally. Other data comes from the Statistical Bulletin of China's Outward Foreign Direct Investment and the China Statistical Yearbook.

(2) Cultural distance (CD). This article refers to the measurement of cultural distance by Qi Jianhong, Li Li et al.[2], and uses the improved KSI index to measure cultural distance:

$$
C D_{i}=\sum_{j=1}^{4}\left[\left(I_{i j}-I_{j C H}\right)^{2} / V_{j}\right] / 4+\left(1 / T_{i}\right)
$$

Among them, $C D$ refers to the cultural distance value of host country $\mathrm{i}$ and China, $\mathrm{I}_{\mathrm{ij}}$ is the cultural distance value of host country dimension $\mathrm{j}, \mathrm{I}_{\mathrm{jCH}}$ refers to the cultural distance value of China dimension $\mathrm{j}$, and $\mathrm{V}_{\mathrm{j}}$ is the variance of cultural distance in $\mathrm{j}$ dimension. $\mathrm{T}_{\mathrm{i}}$ refers to the number of years that China has established diplomatic relations with the B\&R country i. The data comes from the Hofstead Center website (http://geert-hofstede.com).

(3) Geographical distance (DIS). This paper uses the straight line distance between national capitals as a measure of geographical distance, that is, the longitude and latitude distance between Beijing and the capital of the host country. The data comes from the CPEII database.

(4) Host country's GDP(GDP1). GDP reflects changes in economic scale and market demand. Theoretically, the larger the economy of the host country is, the greater the international capital stock it can provide, so it is assumed that the larger the GDP of the host country, the larger the SOFDI. At the same time, the larger China's GDP is, the greater the demand for international capital stock is. Therefore, it is assumed that China's GDP(GDP2) is directly proportional to the spillover host country's R\&D capital stock (SOFDI).

(5) Technology distance (Tech). This paper intends to use the distance between the number of patent applications to measure the technology distance, that is,

Techi, $j=\mid$ Techi-Techj|, $i$ is the host B\&R country, $j$ is China, and the data comes from the world bank database.

(6) R\&D capital stock of the host country(RD).

\subsection{Empirical results and analysis}

Table 1 reports the stepwise regression results of the mixed OLS model using the cultural distance calculated by the improved KSI index as the explanatory variable. It shows that the cultural distance has passed the significance test in the model(1)-(4), and the coefficients are all negative. This shows that the greater the cultural distance, the less outward foreign direct investment China has made in $B \& R$ countries, and the two have a significant negative correlation. Model (1) is a basic gravity model variable. Cultural distance and OFDI reverse technology spillover are significantly negatively correlated at the level of $5 \%$. After adding host country's R\&D capital stock to model (2), cultural distance has a significant negative correlation with OFDI reverse technology spillover at the level of 1\%, which indicates that when controlling the host country 's R\&D capital stock, cultural distance will still negatively affect OFDI's reverse technology spillover, so cultural differences do have a negative impact in OFDI. China must pay more attention to the impact of cultural differences in OFDI activities, We must pay more attention to the impact of cultural differences, in order to avoid economic losses, and bring more reverse technological spillovers.

Geographic distance is significantly negatively correlated in model (4). This shows that the greater the geographic distance between the two countries, the more it will hinder the overflow of China's OFDI R\&D capital stock, which is the same as the results of some articles. Because geographical distance will affect the transaction costs and transportation costs between countries, whether it is trade in goods or services, it will involve the trade and transportation costs between the enterprises of the two countries, so the closer the distance between countries is, the more it will help reduce transaction costs and transportation costs, thereby promoting direct investment between countries. In the B\&R countries, if geographical factors are taken into consideration, the advantages of Central and Eastern European countries are obvious.

The host country's GDP, technology distance, and R\&D capital stock of the host country are significantly positively correlated with SOFDI, which are in line with expectations. The higher the host country's GDP, the higher the domestic consumption level, the larger the market scale and the higher the level of economic development, which is conducive to China's OFDI technology spillover. However, China's GDP is significant only in models (1) and (2), but not in models (3) and (4), indicating that in terms of OFDI reverse technology spillover, China's economic scale and market size will not affect the acquisition of technology spillover. As for the bilateral technology distance, according to the data, the number of patents applied by China each year is greater than the patents of $\mathrm{B} \& \mathrm{R}$ countries, indicating that the development of China's scientific and technological level is greater than that of $B \& R$ countries, and the results of model (3) show that the greater the technology distance, the larger the stock of spillover R\&D capital that China receives from OFDI in B\&R countries, which may be an external advantage brought by OFDI. Generally speaking, when a host country with relatively backward development seeks foreign investment, one purpose is to integrate into the global supply chain, strengthen its own technological level and have some policy support for foreign investment. Naturally, it will also invest in R\&D, so China's OFDI will also increase the level of reverse technology spillovers. 
Table 1 Regression results of the mixed OLS model

\begin{tabular}{|c|c|c|c|c|}
\hline & (1) & (2) & (3) & (4) \\
\hline & LnSOFDI & LnSOFDI & LnSOFDI & LnSOFDI \\
\hline $\mathrm{CD}$ & $\begin{array}{l}-0.096^{* *} \\
(-2.085)\end{array}$ & $\begin{array}{l}-0.225 * * * \\
(-4.925)\end{array}$ & $\begin{array}{l}-0.220 * * * \\
(-4.843)\end{array}$ & $\begin{array}{l}-0.172 * * * \\
(-3.513)\end{array}$ \\
\hline LnGDP1 & $\begin{array}{l}1.658 * * * \\
(19.513)\end{array}$ & $\begin{array}{l}1.286 * * * \\
(13.900)\end{array}$ & $\begin{array}{l}1.306^{* * * *} \\
(14.211)\end{array}$ & $\begin{array}{l}1.240 * * * \\
(13.053)\end{array}$ \\
\hline LnGDP2 & $\begin{array}{l}1.667 * * * \\
(8.545)\end{array}$ & $\begin{array}{l}1.674 * * * \\
(9.267)\end{array}$ & $\begin{array}{l}-0.946 \\
(-0.988)\end{array}$ & $\begin{array}{l}-0.847 \\
(-0.890)\end{array}$ \\
\hline LnRD & & $\begin{array}{l}0.187 * * * \\
(7.660)\end{array}$ & $\begin{array}{l}0.186^{* * * *} \\
(7.682)\end{array}$ & $\begin{array}{l}0.188 * * * \\
(7.809)\end{array}$ \\
\hline LnTech & & & $\begin{array}{l}1.646 * * * \\
(2.787)\end{array}$ & $\begin{array}{l}1.590 * * * \\
(2.711)\end{array}$ \\
\hline LnDIS & & & & $\begin{array}{l}-0.836^{* *} \\
(-2.481)\end{array}$ \\
\hline _cons & $\begin{array}{l}-29.018 * * * \\
(-13.197)\end{array}$ & $\begin{array}{l}-26.467 * * * \\
(-12.824)\end{array}$ & $\begin{array}{l}-18.784 * * * \\
(-5.474)\end{array}$ & $\begin{array}{l}-11.564 * * \\
(-2.581)\end{array}$ \\
\hline $\mathrm{N}$ & 353 & 353 & 353 & 353 \\
\hline $\mathrm{F}$ & 198.680 & 188.309 & 155.131 & 132.223 \\
\hline $\mathrm{R} 2$ & 0.631 & 0.684 & 0.691 & 0.696 \\
\hline
\end{tabular}

Note: The numbers in parentheses are the $t$ values of the regression coefficients. $* * *, * *, *$ represent significant levels at $1 \%, 5 \%$, and $10 \%$.

\section{CONCLUSIONS}

Based on the perspective of cultural differences, by combing domestic and foreign research on FDI and the relationship between cultural differences and FDI, this paper analyzes the cultural distance factors that affect OFDI reverse technology spillover. The paper selects relevant data from 29 sample countries in the B\&R countries from 2005 to 2017, including China's OFDI reverse technology spillover, cultural distance, geographical distance, host country's GDP, China's GDP, technology distance, host country R\&D capital stock, etc. And this paper established panel data for empirical analysis, and examined the impact of cultural differences on reverse technological spillovers of China's outward foreign direct investment in the $\mathrm{B} \& \mathrm{R}$ countries. The results of this paper show that the more obvious the cultural distance is, the more disadvantageous it is for China to obtain reverse technological spillover effects through OFDI. The host country's GDP, technology distance, and host country's R\&D capital stock all contribute significantly to China's OFDI reverse technology spillovers along the Belt and Road countries, and geographical distance is significantly positively correlated with OFDI reverse technology spillovers in the mixed OLS model. After considering the individual effects of each country, geographical distance has no significant effect on OFDI reverse technology spillovers. China's GDP or economic scale, has no obvious impact on China's OFDI reverse technology spillovers along the Belt and Road countries.
Based on this, this article proposes the following policy recommendations:

Firstly, the government should strengthen cultural exchanges with the B\&R countries, and promote 'peopleto-people ties'. The government must increase funds to invest in the construction of cultural systems, reduce information asymmetry between two countries, update the cultural difference, national religious beliefs, cultural taboos, management systems, etc. timely, in order to provide reference for Chinese enterprises to OFDI in B\&R countries, reduce OFDI costs and transaction risks, thus reducing the obstacles of cultural distance to China's OFDI reverse technology spillover.

Secondly, multinational enterprises themselves should also strengthen market research to 'do as the Romans do'. When Chinese enterprises enter the host market, they should first understand and grasp the local cultural environment, recognize the gap in cultural distance between the two sides, and pay attention to the cultural heterogeneity of the two sides in daily management work, technological creation, learning and feedback.

\section{ACKNOWLEDGMENT}

I would like to express my sincere gratitude to Professor Yan. And thanks to my friends who helped me during the writing of this article.

\section{REFERENCES}

[1] Thomas, D.E., Grosse, R., "Country-of-Origin Determinants of Foreign Direct Investment in an Emerging Market: The Case of Mexico,'Journal of International Management, Vol.7, No.1, 2001, p59-79.

[2] Qi Jianhong,Li Li, Yang Li, Location Choice of Chinese OFDI:Based on the Threshold Effect and Test of Cultural Distance, Journal of International Trade(Chinese), 2012(12):137-147.

[3] Andreff, W, "The New Multinational Corporations from Transition Countries,"Economic Systems, Vol.26, No.4, 2002, p.371 379.

[4] Keller, W., "Geographic Localization of International Technology Diffusion," American Economic Review, Vol.92, No.1, 2002, p120 142.

[5] Sha Wenbing, Characteristics of Host Countries and Reverse Technology Spillovers of China' $\mathrm{s}$ Outward FDI: An Empirical Study based on Multinational Panel Data, World Economy Study,2014(5):64-65, 73. 